\title{
A rapid point-of-care assay accurately measures vitamin D
}

\author{
K. Albrecht ${ }^{1} \cdot$ J. Lotz ${ }^{2} \cdot$ L. Frommer ${ }^{1} \cdot$ K. J. Lackner ${ }^{2} \cdot$ G. J. Kahaly ${ }^{1}(\mathbb{C}$ \\ Received: 11 February 2021 / Accepted: 8 April 2021 / Published online: 22 April 2021 \\ (c) The Author(s) 2021
}

\begin{abstract}
Purpose Vitamin D (VitD) is a pleiotropic hormone with effects on a multitude of systems and metabolic pathways. Consequently, the relevance of a sufficiently high VitD serum level becomes self-evident.

Methods A rapid immunofluorescence assay designed for the point-of-care measurement of serum $\mathrm{VitD}_{3}$ solely was tested. Inter- and intra-assay validation, double testing and result comparison with a standardized laboratory method were performed. Results An overall linear correlation of $r=0.89$ (Pearson, 95\% CI 0.88-0.92, $p<0.01$ ) between the point of care and the conventional reference assay was registered. Accuracy and precision were of special interest at cut-points $(10 \mathrm{ng} / \mathrm{ml}[\mathrm{mean}$ deviation $1.7 \mathrm{ng} / \mathrm{ml}$, SD $1.98 \mathrm{ng} / \mathrm{ml}$, SE $0.16 \mathrm{ng} / \mathrm{ml}$ ], $12 \mathrm{ng} / \mathrm{ml}$ [MD 0.41, SD 1.89, SE 0.19] and $30 \mathrm{ng} / \mathrm{ml}$ [MD - 1.11, SD 3.89, SE 0.35]). Only a slight deviation was detected between the two assays when using fresh ( $r=0.91,95 \%$ CI $0.86-0.94$, $p<0.01)$ and frozen serum samples $(r=0.86,0.82-0.89, p<0.01)$. Results remained steady when samples were frozen several times. Inter- and intra-assay validation according to the CLSI protocol as well as multiuser testing showed stable results.

Conclusion This novel, innovative, and controlled study indicates that the evaluated rapid point of care VitD assay is reliable, accurate, and suited for clinical practice.
\end{abstract}

Keywords Vitamin D serum levels $\cdot$ Point-of-care $\cdot$ Rapid assay $\cdot$ Immunofluorescence assay $\cdot$ Chemiluminescence assay

\section{Introduction}

Vitamin D (VitD) is important for healthy living, and its pleiotropic effects go far beyond the mineral metabolism [1-4]. VitD measurement is especially recommended in patients with bone disorders and/or pathologies in calcium homeostasis. VitD is an active steroid hormone, either synthesized from cholesterol or taken in dietary in the form of Cholecalciferol $\left(D_{3}\right)$ or the less potent Ergocalciferol $\left(D_{2}\right)$. However, with the main dietary sources for $\mathrm{D}_{3}$ being fish and for $\mathrm{D}_{2}$ only eggs, milk, and mushrooms, one would not be able to reach sufficient uptake. Thus, the majority of circulating D vitamins originate from bodily production. After hepatic dehydrogenation as well as ultraviolet radiation B (280-315 $\mathrm{nm})$ and heat dependent processing in the skin, the precursor $D_{3}$ is produced [5]. Subsequently, $D_{3}$ is transported back to the liver and converted to $25(\mathrm{OH}) \mathrm{D}_{3}$ by several cytochrome P450 mixed-function oxidases (CYP), such as CYP27A1, CYP3A4, and especially CYP2R1 [6, 7]. $25(\mathrm{OH}) \mathrm{D}_{3}$ is the storage form of $\mathrm{VitD}$, and consequently due to its half-life of 2-3 weeks [8], the best marker to monitor VitD status. $1.25(\mathrm{OH})_{2} \mathrm{D}_{3}$ may impact pathogenesis and 
prognosis of chronic, malignant, and endocrine disease [9-11].

This study was designed to validate a point-of-care diagnostic device for rapid $25(\mathrm{OH}) \mathrm{D}_{3}$ testing. If established, it can be used by primary care practitioners and general physicians, as well as pharmacies and specialized practices without laboratory connection to optimize $25(\mathrm{OH}) \mathrm{D}_{3}$ supplementation.

\section{Materials and methods}

\section{Samples}

Serum samples $(n=324)$ were collected from unselected, consecutively followed subjects with diagnosed endocrine and non-glandular diseases at the academic tertiary referral center for endocrine diseases of the Johannes Gutenberg University (JGU) Medical Center, Mainz, Germany.

Ethical approval was obtained by the local Ethical Committee of the Medical Chamber of the state Rhineland-Palatinate, Germany, and written informed consent was obtained from all subjects. Including validation testing, a total of 433 test runs were performed. Serum was taken from subjects independent of season and either stored or tested immediately after collection. Stored samples were frozen at $-20{ }^{\circ} \mathrm{C}$ $\left(-4^{\circ} \mathrm{F}\right)$. Fresh and frozen samples were each statistically analyzed separately as well as together.

\section{Index assay-Sofia device}

The Sofia Quantitative Vitamin D FIA is a point-of-care (POC) immunofluorescence-based lateral flow assay (Quidel Inc., San Diego, USA). It is designed for in vitro quantitative determination of total $25(\mathrm{OH}) \mathrm{D}_{3}$ using serum samples. Two steps are of immense importance, first serum preparation and secondly reagent application to the test strip. Quantitative testing ability ranges from 10 to $100 \mathrm{ng} / \mathrm{ml}$. If the serum $25(\mathrm{OH}) \mathrm{D}_{3}$ lies below or above aforementioned limits, test results will correspondingly be shown as: " $<10 \mathrm{ng} / \mathrm{ml}$ " or " > $100 \mathrm{ng} / \mathrm{ml}$ ". Complying with CDC recommendation in manufacturer validation, the index assay was correlated with the LC-MS/MS reference method $(r=0.91$ [95\% CI 0.87-0.94]) and thus met VDSP performance criteria [12]. The Quidel Sofia FIA is able to run a high number of point of care assays, which were previously tested. To the extent of our knowledge, there is currently no clinical practice study concerning the total $25(\mathrm{OH}) \mathrm{D}_{3}$ POC.

\section{Index assay sample processing}

To perform the test, a blood sample is collected from the patient and immediately centrifuged at $1300 \times g$ for $10 \mathrm{~min}$.
Frozen or refrigerated samples should be well tempered and well mixed by inverting at least ten times or vortexing. A calibrated micropipette is used to add $100 \mu \mathrm{l}$ of the patient serum sample to the reagent vial, which is then inverted two times for the contents to mix. Subsequently, $5 \mathrm{~min}$ of incubation follow during which $25(\mathrm{OH}) \mathrm{D}_{3}$ molecules are released from VitD-binding proteins (DBP). During incubation, a test mode is selected and user and patient ID are put in either manually or by scanning a barcode. On pressing "start test", a drawer will automatically open. Immediately after five minutes, a micropipette is used to withdraw $120 \mu \mathrm{l}$ of treated solution from the reagent vial and dispensed into the sample well on the test cassette which contains sheep monoclonal anti-25( $\mathrm{OH}) \mathrm{D}_{3}$. The foil pouch containing the test cassette was opened $20 \mathrm{~s}$ before immediate use, avoiding unnecessary environmental exposition as recommended. The test strip contains chemical environments that produce a fluorescent signal indicative for the concentration of total $25(\mathrm{OH}) \mathrm{D}_{3}$ in the patient sample. The fluorescent signal is invisible and must be interpreted by the corresponding device. The test cassette is inserted into the drawer, which is then manually closed. Five minutes of test development start, during which the sample migrates the test strip. Sofia scans the test strip and analyzes the fluorescent signal using method-specific algorithms. Sofia then displays the quantitative result of total $25(\mathrm{OH}) \mathrm{D}_{3}$ on the screen and optionally prints the result with an integrated printer [13].

\section{Validation of the point of care index assay}

To validate and describe the performance data of the device, we conducted several test series with different approaches. The following parameters were determined: random error, constant error, and proportional error. The total validation was divided into two parts [14]: first, the familiarization with the POC device and, second, the experimental evaluation, which itself was divided into a preliminary and final part. The preliminary part calculated the random error, interferences, and recovery. The implementation of the method comparison was part of the final evaluation experiment. The determination of the inter-assay imprecision was replaced by the calculation of the total CV. For determination of random error (intra-assay variation), POC units $(n=20)$ were prepared and measured directly one after another within 1 day. In addition, inter- and intra-assay testing was performed according to the CLSI protocol over the course of 5 days, in the morning and the evening, respectively, adding up to 20 (in total $n=40$ ) test runs each. The two chosen VitD serum concentrations reflect $25(\mathrm{OH}) \mathrm{D}_{3}$-levels of interest, with one being sufficient (30-80 $\mathrm{ng} / \mathrm{ml})$ and one being insufficient $(<30 \mathrm{ng} / \mathrm{ml})$ [15]. Testing for linearity, a recovery experiment was conducted. Two samples with high serum 25(OH) $\mathrm{D}_{3}$ were chosen on behalf of the reference test result. Eleven 
dilutions were prepared each $(100,90,80,70,60,50,40$, $30,20,10$, and $0 \%$ ), using patient serum sample and Dulbecco's Phosphate Buffered Saline (PBS) as diluent. The diluted solution was then tested using the index assay, the results were compared to calculated target values, and the difference between both values was noted. The stability of VitD in serum was verified by testing two samples, frozen and thawed every day, for up to seven cycles over the course of 9 days. Regarding that POC devices are often used by several employees, inter-operator reliability was investigated by five users testing three samples. For method comparison, the POC assay was compared with an established chemiluminescence assay of an automated analyzer. The slope and intercept of the linear regression equation describe the constant and proportional error of the methods. In addition, the coefficient of correlation was calculated.

\section{Reference conventional assay_Abbott Alinity i}

For reference and control, each serum sample was also measured at the JGU central laboratory using an established automated immunoassay. The Alinity i $25-\mathrm{OH}$ Vitamin D Reagent Kit (Abbott, USA) is a delayed one-step immunoassay for quantitative in vitro determination of $25(\mathrm{OH}) \mathrm{D}_{3}$. It is based on the technique of chemiluminescence microparticle immunoassays (CMIA). This assay is standardized against NIST SRM 2972 (National Institute of Standards \& Technology Standard Reference Material 2972) and Clinical and Laboratory Standards Institute (CLSI). For validation, results were compared to isotope dilution liquid chromatography with tandem mass spectrometry (LC-MS/MS) [16]. For this study, only serum samples were used. Quantitative testing ability ranges from 3.5 to $154.2 \mathrm{ng} / \mathrm{ml}$. If the serum $25(\mathrm{OH}) \mathrm{D}_{3}$ lies below or above aforementioned limits, test results will correspondingly be shown as: " $<3.5 \mathrm{ng} / \mathrm{ml}$ " or “> $154.2 \mathrm{ng} / \mathrm{ml} "$.

\section{Reference assay work flow}

Sample, paramagnetic with anti-VitD-coated microparticles, and assay diluent are mixed and incubated. The $25(\mathrm{OH}) \mathrm{D}_{3}$ in the sample is separated from the VitD-binding protein (DBP) and binds to the anti-VitD-coated microparticles. The VitD-acridinium-labeled conjugate is added and a reaction mixture is prepared. The reaction mixture is incubated. After a washing cycle, pre-trigger and trigger solutions are added. The resulting chemiluminescence reaction is expressed in relative light units (RLE) and is measured. The amount of $25-\mathrm{OH}$ VitD in the sample is proportionally related to the RLE measured by the optical system. It takes $1.5 \mathrm{~h}$ from sample input to receipt of the result [16].

\section{Statistical analysis}

Data analysis was performed using Microsoft Excel 16.39 (Microsoft Corporation, Redmond, Washington, USA) and MedCalc ${ }^{\circledR}$ Statistical Software version 19.6 (MedCalc Software Ltd, Ostend, Belgium; https://www.medcalc.org; 2020). Pearson and Lin correlation were implemented, as well as Passing Bablok regression [17, 18], which is used to detect correlations as well as constant and proportional bias between the index point of care and reference assay results. The model is suited for method comparison due to its immunity towards outliners. Results are also presented as Bland-Altman plot to show the difference between index and reference results plotted against their mean. This allows to find a correlation between a measurement error and the estimated true value [19]. The significance level was $5 \%(\alpha=0.05)$.

\section{Results}

\section{A. Demographic and serological data}

A total of 324 serum samples from unselected, consecutively followed outpatients with endocrine and nonendocrine diseases, were collected. In detail, patients with various thyroid diseases, type 1 and 2 diabetes, metabolic syndrome, monoglandular and polyglandular autoimmunity were included. Individual medication was considered during analysis. Of these, 296 samples were included in this comparison study (229 females and 67 males, 156 smokers), with an average age of 48.1 years (range 6.8-84.0 years). Twenty-eight samples outside of the measuring range of the index assay (10-100 $\mathrm{ng} / \mathrm{ml})$ were documented and then excluded due to falsification of correlation results. The falsification of the results is caused by the limitations of the measuring range. Values far above or below this range will result in large absolute deviations if viewed out of context, although the index assay can correctly indicate that the value is outside its range. Of the 28 excluded samples, one sample only was above $100 \mathrm{ng} / \mathrm{ml}$, while 27 samples were below $10 \mathrm{ng} /$ $\mathrm{ml}$. 18 of these samples were also measured $<10 \mathrm{ng} / \mathrm{ml}$ by the Abbott Alinity i and nine were measured $>10 \mathrm{ng} /$ $\mathrm{ml}$. Furthermore, serum samples were divided into fresh $(N=88)$ and frozen samples $(N=208)$. A total of 45 patients reported VitD substitution, of whom only one showed $25(\mathrm{OH}) \mathrm{D}_{3}$ serum levels above $100 \mathrm{ng} / \mathrm{ml}$.

\section{B. Overall results with both devices}

The arithmetical mean for the index assay was $28.5 \mathrm{ng} / \mathrm{ml}$ (SD [standard deviation] $14.17 \mathrm{ng} / \mathrm{ml} ; \mathrm{SE}$ [standard error] $0.82 \mathrm{ng} / \mathrm{ml}$; CV [coefficient of variation] $50 \%$ ), while the median was $24.6 \mathrm{ng} / \mathrm{ml}$. In comparison, the arithmetical mean for the reference assay and the 
median were $30.2 \mathrm{ng} / \mathrm{ml}$ (SD $15.96 \mathrm{ng} / \mathrm{ml}$; SE $0.93 \mathrm{ng} /$ $\mathrm{ml}$; CV 53\%) and $25.7 \mathrm{ng} / \mathrm{ml}$, respectively $(p<0.01)$. The correlation factor was 0.89 . Due to the design of the study, it was verified using Lin's Concordance Correlation Coefficient $\left(\operatorname{Lin}_{\mathrm{CCC}} ; \mathrm{r}_{\mathrm{c}}\right)$, which showed minimal deviation $\left(r_{c}=0.88\right.$; 95\% CI 0.85-0.9) when compared to the Pearson's correlation coefficient [20]. Accuracy and precision were calculated at $10 \mathrm{ng} / \mathrm{ml}(95 \%$ $\mathrm{CI} \pm 1.21$, mean deviation $1.7 \mathrm{ng} / \mathrm{ml}, \mathrm{SD} 1.98 \mathrm{ng} / \mathrm{ml}$, SE $0.16 \mathrm{ng} / \mathrm{ml}), 12 \mathrm{ng} / \mathrm{ml}$ (95\% CI \pm 1.1 , MD 0.41, SD 1.89 , SE 0.19), and $30 \mathrm{ng} / \mathrm{ml}$ (MD - 1.11, SD 3.89, SE
0.35). The Passing Bablok regression and the BlandAltman plot analysis are shown in Figs. 1 and 2. Aiming to see whether or not frozen serum samples would produce a comparably strong test power, fresh (Index assay median $=24.8 \mathrm{ng} / \mathrm{ml}[\mathrm{SD} 11.7 \mathrm{ng} / \mathrm{ml}]$, reference assay median $=26.1 \mathrm{ng} / \mathrm{ml}[\mathrm{SD} 14.4 \mathrm{ng} / \mathrm{ml}]$ ) and frozen samples (Index assay median $=27 \mathrm{ng} / \mathrm{ml}[\mathrm{SD} 15 \mathrm{ng} / \mathrm{ml}]$, reference assay median $=27.3 \mathrm{ng} / \mathrm{ml}[\mathrm{SD} 16.6 \mathrm{ng} / \mathrm{ml}]$ ) were analyzed separately. The Passing Bablok regressions are shown in Fig. 3.
Fig. 1 Passing Bablok regression for all samples. $N=296$ samples, Pearson correlation $r=0.89$ (95\% CI 0.88-0.92, $p<0.01), \mathrm{y}=1.312+0.910 \mathrm{x}$. Intercept $\mathrm{A}=1.31(95 \% \mathrm{CI}$

-0.27 to 2.9. Slope $\mathrm{B}=0.91$ (95\% CI 0.86-0.97)
Fig. 2 Bland-Altman plot for all samples. It shows the difference in results of both assays plotted against their means. The values scatter coincidentally, without systematic deviation
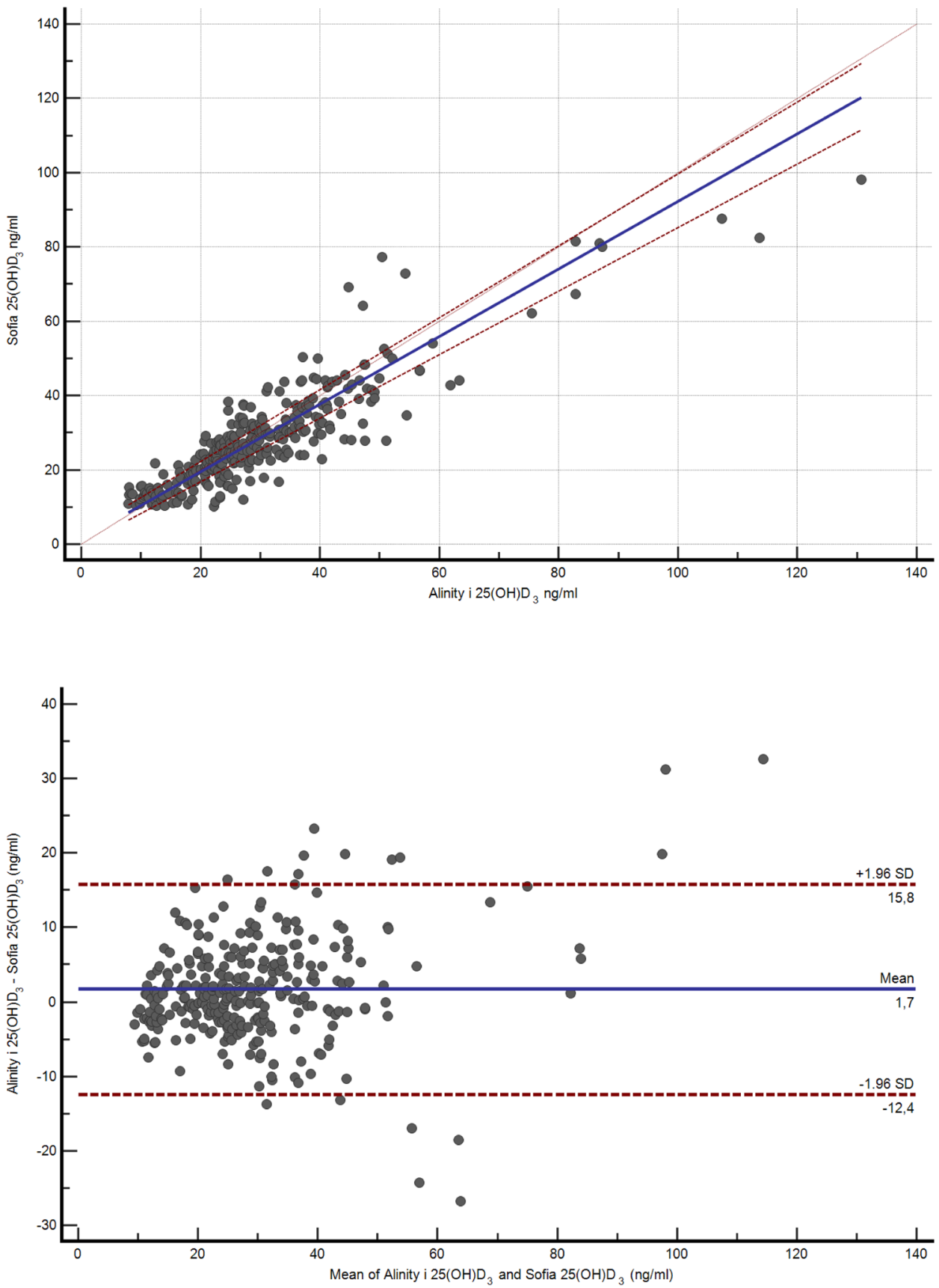
A

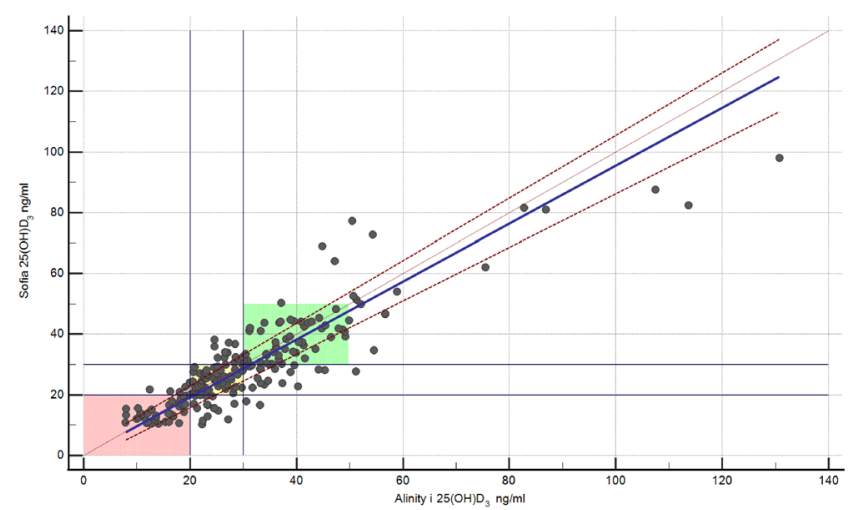

Fig. 3 a, b Comparison of fresh versus frozen samples. a Passing Bablok regression for frozen samples $(n=208), r=0.89(95 \%$ CI $0.85-0.91), p<0.01, \mathrm{y}=0.120+0.954 \mathrm{x}, r_{c}=0.87$ (95\% CI $0.84-$ 0.89). b Passing Bablok regression for fresh samples $(n=88), r=0.92$ (95\% CI 0.87-0.94), $p<0.01, \mathrm{y}=3.506+0.805 \mathrm{x}, r_{c}=0.89(95 \%$ CI $0.87-0.91)$. Green: sufficient VitD serum levels (30-80 ng/ml), yel-

\section{Precision data of the Sofia point of care assay}

The linearity was assessed using two dilution series (Fig. 4). Deviation ranges from -6.3 to $11.5 \mathrm{ng} / \mathrm{ml}$. Sofia test results for steps $20 \%$ to $0 \%$ were always displayed as:" < $10 \mathrm{ng} / \mathrm{ml}$ ". According to the CLSI protocol, two samples representing the region of interest at a low (mean $=17.58 \mathrm{ng} / \mathrm{ml}, \mathrm{SD}=2.61 \mathrm{ng} / \mathrm{ml}, \mathrm{CV}$ 14.86, interassay CV 5.13) and a high serum level (mean $=49.5 \mathrm{ng} / \mathrm{ml}, \mathrm{SD}=4.72 \mathrm{ng} / \mathrm{ml}, \mathrm{CV}=9.53$, interassay CV 7.34) were each measured two times a day (at 8 am and at 4 p.m.) in double determination. To test

A

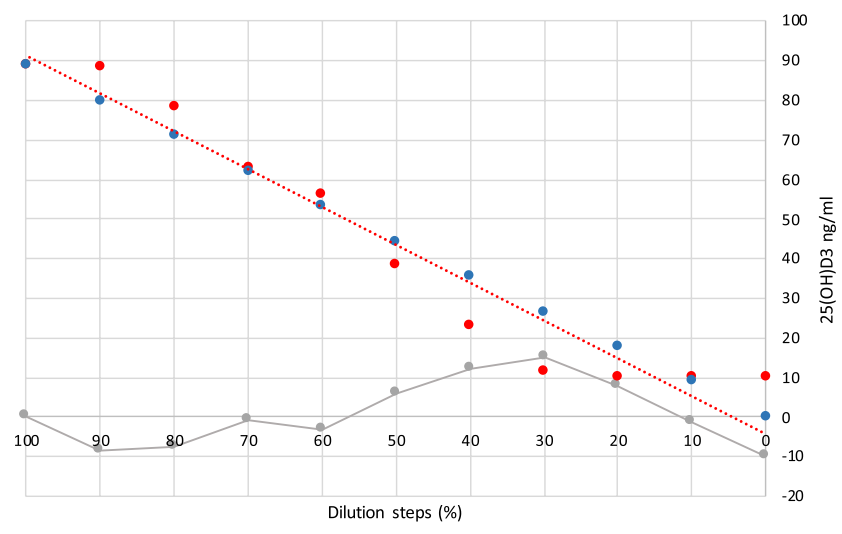

Fig. 4 a, b Test for linearity. Two serum samples were diluted eleven times each $(100,90,80,70,60,50,40,30,20,10$ and $0 \%)$ a Dilution of a serum sample at $89 \mathrm{ng} / \mathrm{ml}$ VitD. Deviation ranges from -8 to $15 \mathrm{ng} / \mathrm{ml}$ maximum, mean $=0.9 \mathrm{ng} / \mathrm{ml}(\mathrm{SD}=8.4 \mathrm{ng} / \mathrm{ml})$. b
B

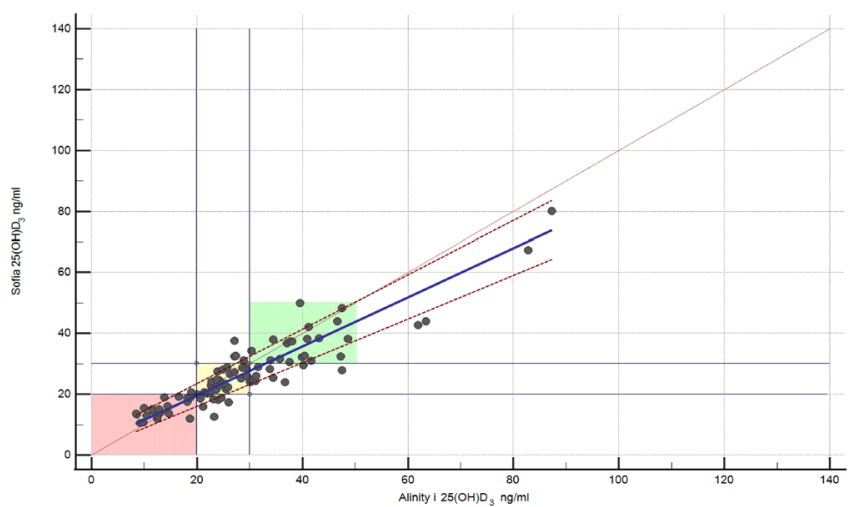

low: insufficient levels $(20-29 \mathrm{ng} / \mathrm{ml})$, red: deficient serum levels $(<19 \mathrm{ng} / \mathrm{ml})$. Sofia $($ Quidel $)=$ Index assay; Alinity i $($ Abbott $)=$ reference assay; frozen samples were stored at $-20^{\circ} \mathrm{C}\left(-4^{\circ} \mathrm{F}\right)$, fresh samples were tested immediately after collection and sample preparation

for imprecision, a total coefficient of variation (CV) was calculated and found at $15.1 \%$ for the sample with low VitD level and 9\% for the sample with high VitD level (Fig. 5). Multi-operator validation was performed by five operators testing three samples at deficient, insufficient, and sufficient (13, 27 and $33 \mathrm{ng} / \mathrm{ml})$ VitD serum levels up to two times. Standard deviation (SD $[\mathrm{ng} / \mathrm{ml}]$ ) ranged from 0.9 to 2.9 ; with a $\mathrm{CV}$ of $7-8 \%$. Two samples were frozen and thawed every day over the course of 7 days, stress testing the stability of VitD in serum samples and verifying inter-assay variability (Fig. 6).
B

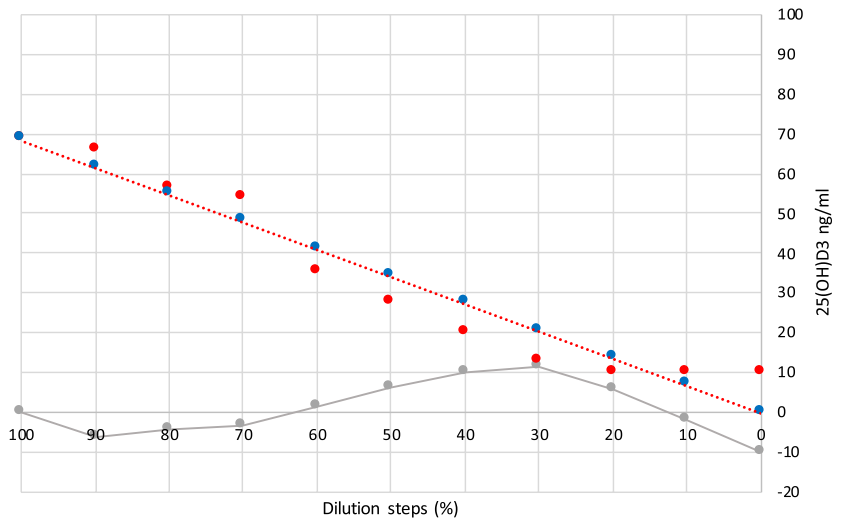

Serum level of $66 \mathrm{ng} / \mathrm{ml}$ VitD. Deviation ranges from -6 to $7 \mathrm{ng} /$ $\mathrm{ml}$ maximum, mean $=0.6 \mathrm{ng} / \mathrm{ml}(\mathrm{SD}=6 \mathrm{ng} / \mathrm{ml})$. Blue: Target value, red: measured result, grey: difference between expected and measured value $(\mathrm{ng} / \mathrm{ml})$ 
Fig. 5 Determination of imprecision. Testing for total CV according to the CLSI protocol. Two serum samples were tested four times a day, twice in the morning and twice in the evening over the course of 5 days. Total CV was 15.1 and $9 \%$ for the samples with low and high VitD levels, respectively. Blue and red along one trendline represent the lower (blue) and higher (red) test result
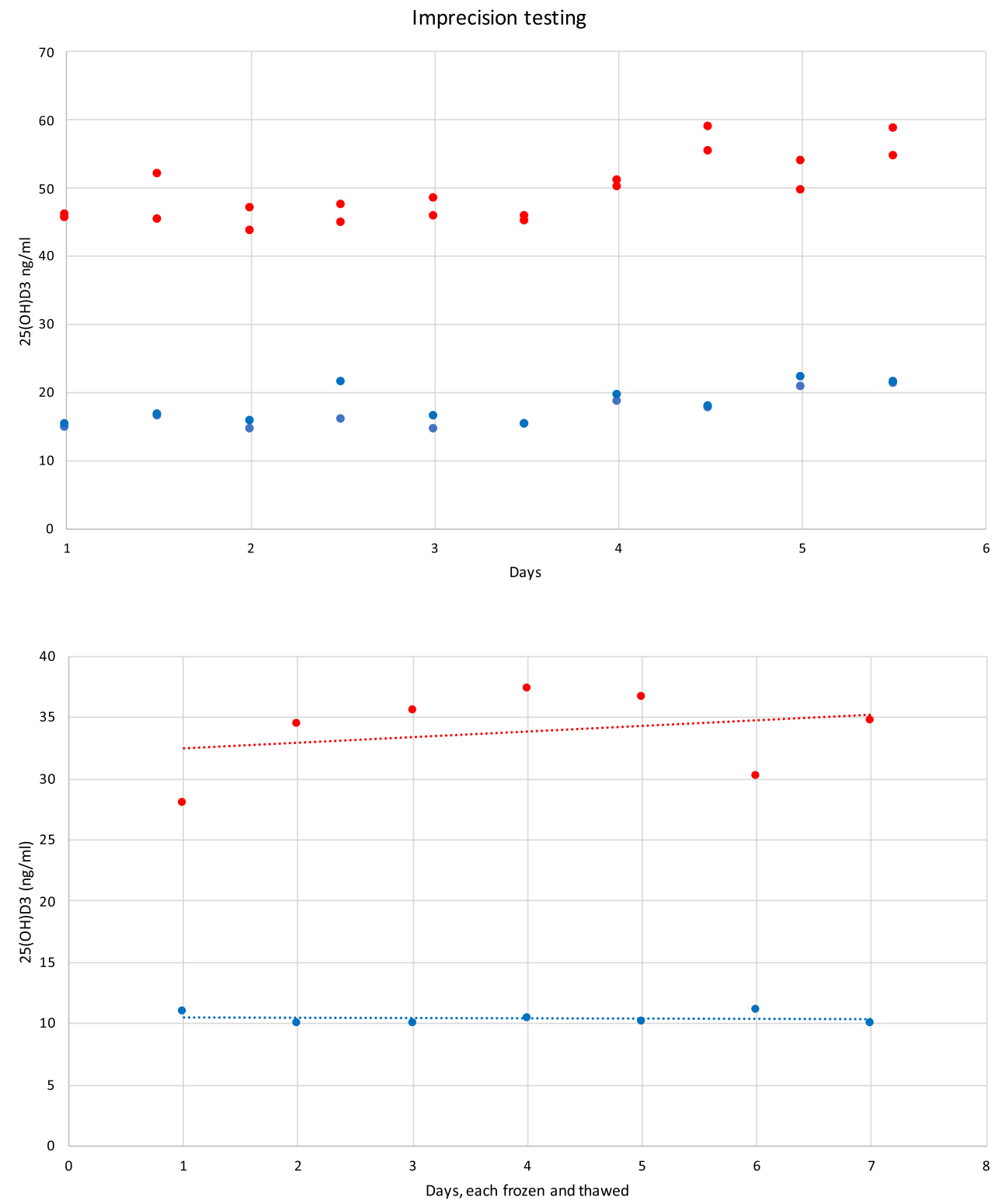

Fig. 6 Inter-assay and stress testing. $\mathrm{N}=$ two samples, frozen and thawed every day over the course of 7 days. SD ranged from $0.5 \mathrm{ng} / \mathrm{ml}$ (low serum VitD, blue) to $3.5 \mathrm{ng} / \mathrm{ml}$ (high serum VitD, red), CV from 5 (low VitD) to 10\% (high VitD)

\section{Discussion}

This novel and innovative controlled study demonstrates the accuracy of an easy to handle point of care device for the rapid and quantitative measurement of $25(\mathrm{OH}) \mathrm{D}_{3}$ in the serum of a large number of unselected and consecutively followed outpatients with various endocrine and non-glandular diseases. Compared to a conventional methodology in the university central lab, this small device offered acceptable and reliable serum VitD values with an overall correlation of approximately $90 \%$ between both assays. Although requests of the American/European Chemistry Societies and/or Laboratory Medicine for correlations around 98-99\% prevail, the same standards cannot be applied for a point of care device. Hence, a second test with a standard method might be indicated if $25(\mathrm{OH})$ $\mathrm{D}$ values $<30 \mathrm{ng} / \mathrm{ml}$ are found, to properly address VitD supplementations according to national and international guidelines.

The rationale for this study was to compare the reliability and acceptable accuracy of this rapid, convenient, and simple methodology in daily routine. In the light of the above, we found a device that offers a very good comparability to an established method. The measuring range covers the clinically relevant spectrum from absolute deficiency to the toxic edge sufficiently. The results are stable over time and the device is easy to work with. Despite slightly lower concentration results with the Sofia device, the subgroup categorization between deficiency, insufficiency, and sufficiency is satisfactory. Once confirmed, point of care measurement of serum VitD could 
be performed reliably, rapidly, and easily in each clinical practice and pharmacy worldwide.

In detail, the coefficients of correlation were similar in fresh and frozen samples ( $r=0.92$ and $r=0.89$, respectively), with a slightly smaller deviation when testing fresh samples. Results were less accurate for VitD serum levels above $100 \mathrm{ng} / \mathrm{ml}$. Only one patient achieved correspondingly high values on VitD substitution, which is why currently, we cannot exclude the possibility that this impacts the assay in terms of specificity. While the standard reference method gave results in the toxic range, the point of care assay still measured below toxicity. Therefore, for concentrations above $80 \mathrm{ng} / \mathrm{ml}$ and to be on the safe side, we recommend an additional test with a standard method. The linearity check (dilution with buffer) showed a slight overestimation at dilutions with 10-20\% dilution medium in the test preparation, and an underestimation at dilutions greater than 1:2. This could possibly be attributed to a matrix effect due to the higher non-protein content, evoking changed flow properties. The imprecision test was performed on frozen samples. Both sera were frozen once, thawed, and then stored in the refrigerator for 5 days. During these 5 days, the results increased slightly and a continuous drift could be observed. Whether this is due to the storage form and a possibly increasing instability of the VitD-DBP complex cannot be determined with certainty. Samples delivered stable results when frozen several times with a coefficient of variation of less than $10 \%$; identical applies to multiple users testing the same serum sample. Finally, stress testing delivered very satisfying results. Overall, this indicates that the influence on the assay performance through handling is not critical. This is a very important aspect when operating a point of care analyzer.

The individual VitD status is influenced by diet, sun exposure, skin pigmentation, age, and BMI. Genetic factors also play an important role [9]. Several studies analyzed serum levels of $25(\mathrm{OH}) \mathrm{D}_{3}$ for a wide range of countries, showing that hypovitaminosis $\mathrm{D}$ is a worldwide issue of concern. Especially, pregnant women, newborn children, and elderly people are at high risk of insufficiency and its consequences [21]. As hypovitaminosis, hypervitaminosis D carries risks as well by $25(\mathrm{OH}) \mathrm{D}_{3}$ acting toxic above serum levels of $150 \mathrm{ng} / \mathrm{ml}$ [22]. Respectively, the American Endocrine Society advises to screen patients at risk for deficiency. $25(\mathrm{OH}) \mathrm{D}_{3}$ levels below $30 \mathrm{ng} / \mathrm{ml}$ are declared insufficient, while levels below $20 \mathrm{ng} / \mathrm{ml}$ rate as deficient [15]. Although the optimal serum level could not yet be determined, the American Geriatrics Society recommends minimum serum levels of $30 \mathrm{ng} / \mathrm{ml}$ as well [23]. While the importance of a sufficiently high VitD level is evident, the establishment of official guidelines and benchmarks has proven difficult, and still does so. This is due to the vast amount of different assays available within the field and lack of standardization resulting in wide intra-assay variation and inter-assay variability. Against the backdrop of this inconsistency, the interpretation of study results in form of systematic reviews is prevented. To achieve uniformly usable results and establish globally valid guidelines, the Vitamin D Standardization Program (VDSP) and the Vitamin D External Quality Assurance Scheme (DEQAS) were founded. The VDSP was created in 2010 by the National Institutes of Health (NIH), the Centers for Disease Control and Prevention (CDC) and others. The goal was and is to standardize new assays using the reference measurement procedures (RMPs) operated by Ghent University, National Institute for Standards and Technology (NIST) and the CDC. Both RMPs operate using isotope dilution liquid chromatography with tandem mass spectrometry (LC-MS/MS) and are defined as the gold standards regarding determination and measurement of the true 25(OH)D serum level [12, 24]. The DEQAS operating by CDC standardization has been monitoring laboratories assaying $25(\mathrm{OH}) \mathrm{D}$ quarterly over the last 30 years. Another factor that complicates the measurement of reliable values is the interference of variables with the assays. For example, the supplementation of ergocalciferol $\left(D_{2}\right)$ or varying affinity and release from vitamin D-binding protein (DBP) $[25,26]$. Complying with VDSP recommendations, the introduced index point of care assay met CDC criteria.

In conclusion, the novel and encouraging data indicate that the evaluated point of care assay for the rapid measurement of serum VitD is reliable, accurate, and suited for clinical practice.

Acknowledgements The critical review of the manuscript by Drs. Werner Kroll and Dipesh Jaiswal, Quidel, USA is appreciated.

Author contributions GJK: initiation of the project, logistical and financial support, data interpretation, drafting the article, editing and approval of the final version. KA: lab work, literature search, data interpretation, drafting the article. JL, LF, and KL: critical discussion of data, editing, and revision of the article.

Funding Open Access funding enabled and organized by Projekt DEAL. The JGU Medical Center has received research-associated funding from Quidel, USA.

\section{Declarations}

Conflict of interest GJK consults for Quidel. The other authors have nothing to disclose.

Ethical approval Ethical approval was obtained by local Ethical Committee of the Medical Chamber of the state Rhineland-Palatinate, Germany.

Informed consent Written informed consent was obtained from all patients. 
Open Access This article is licensed under a Creative Commons Attribution 4.0 International License, which permits use, sharing, adaptation, distribution and reproduction in any medium or format, as long as you give appropriate credit to the original author(s) and the source, provide a link to the Creative Commons licence, and indicate if changes were made. The images or other third party material in this article are included in the article's Creative Commons licence, unless indicated otherwise in a credit line to the material. If material is not included in the article's Creative Commons licence and your intended use is not permitted by statutory regulation or exceeds the permitted use, you will need to obtain permission directly from the copyright holder. To view a copy of this licence, visit http://creativecommons.org/licenses/by/4.0/.

\section{References}

1. Saponaro F, Marcocci C, Zucchi R (2019) Vitamin D status and cardiovascular outcome. J Endocrinol Invest 42(11):1285-1290

2. Barale M, Rossetto Giaccherino R, Ghigo E, Procopio M (2020) Effect of 1-year oral cholecalciferol on a metabolic profile and blood pressure in poor-controlled type 2 diabetes mellitus: an open-label randomized controlled pilot study. J Endocrinol Invest 44(4):791-802

3. Song A, Zhao H, Yang Y, Liu S, Nie M, Wang O, Xing X (2021) Safety and efficacy of common vitamin D supplementation in primary hyperparathyroidism and coexistent vitamin D deficiency and insufficiency: a systematic review and meta-analysis. J Endocrinol Invest. https://doi.org/10.1007/s40618-020-01473-5

4. Panfili FM, Roversi M, D’Argenio P, Rossi P, Cappa M, Fintini D (2021) Possible role of vitamin D in Covid-19 infection in pediatric population. J Endocrinol Invest 44(1):27-35

5. Christakos S, Li S, De La Cruz J, Bikle DD (2019) New developments in our understanding of vitamin metabolism, action and treatment. Metabolism 98:112-120

6. Christakos S, Dhawan P, Verstuyf A, Verlinden L, Carmeliet G (2016) Vitamin D: metabolism, molecular mechanism of action, and pleiotropic effects. Physiol Rev 96(1):365-408

7. Pike JW, Christakos S (2017) Biology and mechanisms of action of the vitamin D hormone. Endocrinol Metab Clin North Am 46(4):815-843

8. Miteva MZ, Nonchev BI, Orbetzova MM, Stoencheva SD (2020) Vitamin D and Autoimmune Thyroid Diseases - a Review. Folia Med (Plovdiv) 62(2):223-229

9. Carlberg C (2015) What do we learn from the genome-wide perspective on vitamin D3? Anticancer Res 35(2):1143-1151

10. Altieri B, Muscogiuri G, Barrea L, Mathieu C, Vallone CV, Mascitelli L, Bizzaro G, Altieri VM, Tirabassi G, Balercia G, Savastano S, Bizzaro N, Ronchi CL, Colao A, Pontecorvi A, Della CS (2017) Does vitamin D play a role in autoimmune endocrine disorders? A proof of concept. Rev Endocr Metab Disord 18(3):335-346

11. Veneti S, Anagnostis P, Adamidou F, Artzouchaltzi AM, Boboridis K, Kita M (2019) Association between vitamin D receptor gene polymorphisms and Graves' disease: a systematic review and meta-analysis. Endocrine 65(2):244-251

12. Wise SA, Phinney KW, Tai SS-C, Camara JE, Myers GL, DurazoArvizu R, Tian L, Hoofnagle AN, Bachmann LM, Young IS, Pettit J, Caldwell G, Liu A, Brooks SPJ, Sarafin K, Thamm M, Mensink GBM, Busch M, Rabenberg M, Cashman KD, Kiely M, Kinsella M, Galvin K, Zhang JY, Oh K, Lee S-W, Jung CL, Cox
L, Goldberg G, Guberg K, Prentice A, Carter GD, Jones J, Brannon PM, Lucas RM, Crump PM, Cavalier E, Merkel J, Betz JM, Sempos CT (2019) Baseline assessment of 25-Hydroxyvitamin D assay performance: a vitamin D standardization program (VDSP) interlaboratory comparison study. J AOAC Int 100(5):1244-1252

13. Quidel. Sofia Quantitative Vitamin D FIA [Manual]. quidel. com2019 [Available from: https://www.quidel.com/sites/default/ files/product/documents/EF1282220XX00_\%2802_19\%29_PI_ Sofia_Vitamin_D_FIA_Pkg_Inserts_DE_IT_FR_ES_PT.pdf

14. Westgard JO (2003) Basic method validation, 2nd edn. Westgard Quality Corporation, pp 48-55

15. Holick MF, Binkley NC, Bischoff-Ferrari HA, Gordon CM, Hanley DA, Heaney RP, Murad MH, Weaver CM (2011) Evaluation, treatment, and prevention of vitamin D deficiency: an Endocrine Society clinical practice guideline. J Clin Endocrinol Metab 96(7):1911-1930

16. Abbott Laboratories (2016) Alinity i: 25-OH Vitamin D Reagent Kit. A Laboratory Editor 1:1-4

17. Passing H, Bablok W (1983) A new biometrical procedure for testing the equality of measurements from two different analytical methods. Application of linear regression procedures for method comparison studies in clinical chemistry, Part I. J Clin Chem Clin Biochem. 21(11):709-720

18. Passing H, Bablok W (1984) Comparison of several regression procedures for method comparison studies and determination of sample sizes. Application of linear regression procedures for method comparison studies in Clinical Chemistry, Part II. J Clin Chem Clin Biochem. 22(6):431-445

19. Bland JM, Altman DG (1986) Statistical methods for assessing agreement between two methods of clinical measurement. Lancet 1(8476):307-310

20. Zaiontz C (2020) Lin's concordance correlation coefficient real statistics. WordPress. Available from: https://www.real-statistics. com/reliability/interrater-reliability/lins-concordance-correlationcoefficient/. Accessed 13 Nov 2020

21. van Schoor NM, Lips P (2011) Worldwide vitamin D status. Best Pract Res Clin Endocrinol Metab 25(4):671-680

22. Marcinowska-Suchowierska E, Kupisz-Urbańska M, Łukaszkiewicz J, Płudowski P, Jones G (2018) Vitamin D toxicityA clinical perspective. Front Endocrinol (Lausanne) 9:550

23. American Geriatrics Society Workgroup on Vitamin D Supplementation for Older Adults (2014) Recommendations abstracted from the American Geriatrics Society Consensus Statement on vitamin D for prevention of falls and their consequences. J Am Geriatr Soc 62(1):147-152

24. Binkley N, Sempos CT (2014) Standardizing vitamin D assays: the way forward. J Bone Miner Res 29(8):1709-1714

25. Giustina A, Bouillon R, Binkley N, Sempos C, Adler RA, Bollerslev J, Dawson-Hughes B, Ebeling PR, Feldman D, Heijboer A, Jones G, Kovacs CS, Lazaretti-Castro M, Lips P, Marcocci C, Minisola S, Napoli N, Rizzoli R, Scragg R, White JH, Formenti AM, Bilezikian JP (2020) Controversies in vitamin D: a statement from the third international conference. JBMR Plus 4(12):e10417

26. Binkley NC, Wiebe DA (2018) It's time to stop prescribing ergocalciferol. Endocr Pract 24(12):1099-1102

Publisher's Note Springer Nature remains neutral with regard to jurisdictional claims in published maps and institutional affiliations. 